ISSN 2726-6818

UDC 416.731.421.

DOI https://doi.org/10.46805/dogma/maltsevolegbaudrillardphilosophy

\title{
Philosophical judgment of memory phenomenon methodological conceptualization in the study of J. Baudrillard's legacy
}

Phd Maltsev Oleg ${ }^{1}$

\begin{abstract}
Current trends determine the prerequisites of praxeological and epistemological understanding of sustainable social development vector, as well as relevant strategies for the educational improvement aimed at gaining relevant skills that allow one to achieve his goals and results. Since global world transformations correlated to overwhelming systemic crises and contradictions as well as the transition of humanity lead to a new course of civilizational development characterized by dynamic processes of digitization, the spread of hyperreality, the transition of human activity are merging within a virtual dimension.

The purpose of the following scientific exploration is to apply the heuristic memory models knowledge to the interpretation of the praxeological results within methodological conceptualisation; it is directed at analyzing the heritage of Jean Baudrillard's personality, his projects, contributions to the development of philosophy and academics; issues preserved in the living memory of experts for methodological value in education and self-education, in the practice of developing the skills, as well as relevant skills regarding the next generations.

\footnotetext{
${ }^{1}$ multiple Ph.D (psychology, philosophy), author, psychologist, researcher, criminologist. Academician of Ukrainian Academy of Sciences. Founder and director of The Memory Institute, Head of Odessa Regional Branch of the UAS, head of Expeditionary Corps, chairman of Odessa Photographic Scientific Society, Ukraine. Author of numerous books in the areas such as applied history, sociology, depth psychology, philosophy, criminalistics, criminology. Email: olegmaltsev@baudrillard-scijournal.com
} 
2 Édition Printemps - Été 2019

As a result of our scientific report, we shall consider the role and influence of the environment and the "constructs" of world memory and history on the formation of the memory of the personality, its works, achievements, and fruits of creativity, on the determination of the contents of the personality's memory, and also on how these data can be used in modern conditions for the activity approach.

Based on the principle of unity of theory and practice, we managed to develop a system of practice-philosophical analysis in the application of semi-structured interviews experts, who are followers, successors, critics and independent researchers, i.e., the "Carrier data" of the philosophical, anthropological, psychological and sociological memory inheritance of Jean Baudrillard, the 'productive' figure in history, who for a reason is also the subject claimed to be the "Europe's last prophet".

Regarding the activity approach, we have applied works of academician G. Popov, in the tradition of his school and in solidarity with his concepts of activity approach to the study of generations' memory, thus, we analyze effective models in teaching and training relevant skills in the individual, verified by the requirements of society, such a philosophical judgment devoted to the understanding of ontological, epistemological, axiological and praxeological aspects of further analysis.

Analyzing the issues of the scientific exploration, we shall examine the role and influence of the environment and world memory "constructs" and history on the memory formation of an authentic person, his works, achievements and results of creativity, on the perception of memory content of an individual, as well as on wherewith these data may be used in concurrent conditions from an active approach to the philosophical and practical result of methodologies and information technologies appropriate and assuring in the 21 st century.

Keywords: memory, phenomenology of memory, memory technologies, heritage of J. Baudrillard, activity approach, skills, philosophy of profession.

\section{Introduction}

In the article, we present the results of the applied measurement of philosophical judgment of conceptualization and theoretical models of the memory phenomenon in the study of the legacy of the philosopher and sociologist, expert and scholar Jean Baudrillard, an outstanding French thinker of the late twentieth and early twenty-first century, "Father of postmodernism", author of more than 30 books, which on the one hand, provoked a number of discussions and controversies, on the other hand, awarded Jean Baudrillard the second name of "European last prophet". 
3 Édition Printemps - Été 2019

The reflection of the memory of Jean Baudrillard in a semi-structured interview is based on the latter essential provisions: firstly, since the principle of objectivity is the key principle of interpretation in the philosophical practice of methodology, we managed to work with initial sources in our scientific theory. The principal sources include not only the works, books of J. Baudrillard, interview materials recorded with him throughout his lifetime that there are documentary objects, but also the circle of people who knew Jean Baudrillard personally. Hence, we chose to explore the "oral history", a living representation of the heritage of J. Baudrillard.

The following study completes the responsibility to consider the impact of the memory phenomenon approaching a specific example of the historical results of the life of the expert J. Baudrillard in the "living" social memory, as well as it "eyewitnesses" his activities and those people, who study his legacy regarding books, interviews, memories, i.e. the results reached and implemented through his life.

The results of the individual - this is one of the key categories, which form the basis of memory about the personality, i.e. its essence, the soil. Since the object of analysis is the results of the activity of the personality of the French philosopher Jean Baudrillard, and the subject - his legacy in living memory of scientists, the ground may be his completed works and concepts, described in a number of books ("Simulacra and simulations", "America", "Perfect crime", "Transparency of Evil", "Fatal strategies" and many others). Notwithstanding, the analysis of the results of the thinker in the form of books, entries, articles, interviews, etc. is not complete, since it is only one block of data: and data, which personality reflected in the kind of activity results: documentary, photo- and video-sources in the course of life and activity, no less meaningful is the subjective system, of people who have been aware, and which is practiced in the activities of other experts.

In our scientific research, we present the original sources as analyzed data, i.e., interview results, conducted with the expert set, whose participants position themselves as friends, followers of J. Baudrillard, or his critics, or acting as independent researchers; they represent the sources of new data, allows one to analyze the memory as a clear heritage of this historical figure in accordance with the logic of "authority - habit - training program - environment", as well as in practical research aiming to detect the way the study of memory of personality passes through the transformation steps of the data into practical skills.

Overall, we have developed the following epistemological and axiological system of approaches to working with primary sources. Since the works and books of Jean 
4 Édition Printemps - Été 2019

Baudrillard - this is the primary data, available for comprehension, having analyzed the current literature, we devoted the research focus to the life and work of J. Baudrillard. Hence, already at the start of the study of the phenomenon of memory formation personality in generations we have come to the conclusion, that unfortunately, the data base and system of sources is not just insufficient, but poor (especially in Ukraine- and the Russian-speaking segment). In accordance, the author of this scientific investigation decided to organize a research project "Heritage of the Jean Baudrillard School», within which the Institute of Memory in 2019 organized and conducted interviews with world remarkable scientists, i.e., individuals and philosophers in science, who definitely possess the reason to speak of Baudrillard life and professional activity, his concepts and legacy.

The goal of our scientific exploration is to apply the heuristic memory models knowledge to the praxeological results interpretation within methodological conceptualisation; it is directed at analyzing the heritage of Jean Baudrillard's personality, his projects, contributions to the development of philosophy and science; issues preserved in the living memory of experts for methodological value in education and self-education, in the practice of developing the skills, as well as relevant skills regarding the next generations.

Regarding the principle of unity of theory and practice, which is a fundamental philosophical and methodological principle, we believe it is relevant to define the logic of our study, based on knowledge of practical research of heuristic models of memory, practical for the research of problematic and unknown aspects of personal training and acquisition of actual skills.

\section{Materials and methods}

In the following article, a theoretical model of ontological and epistemological understanding of the figure's heritage potential impact in memory of the generations (through the prism of the activity approach) is applied. Furthermore, we studied the model of academician G. Popov, termed "model of dynamic memory blocks", consisting of four blocks (Popov, 1949).

Qualitative practical philosophical judgment of the fundamental principles and attributive features of this model is also outlined in this article. In the prospect, analyzing the concept of the theoretical model, as it contains an ontological, epistemological, axiological and praxeological aspects, we applied these aspects to the memory heritage of our study object, i.e. the heritage of Jean Baudrillard, for the practical 
5 Édition Printemps - Été 2019

analysis purpose, as well as validation of this model and axiological conclusion of value and significant aspects of the heritage of W. Baudrillard in the plane of 'metatheory', self-study and education in terms of activity approach, taking into account the level and order of XXI century tasks.

Being followers of the teachings of Academician G. Popov, we share the position of the scientist, the author of the concept of memory and the constructor of the heuristic model of memory formation; we also consider, every person is known "by his deeds" and the reason for the memory formation is the resulting scope of personal activity, the one, achieved in his lifetime, i.e. "core points of the coordinate system", created by man in intercommunication with society and the external environment, taking into account differences in space-time terms.

Considering the activity approach we have associated works of academician G. Popov, in the tradition of his school and solidarity with his concepts of activity approach to the study of generations' memory, consequently, we examine effective teachings in training and educating relevant skills in the individual, verified by the requirements of civilization, such a philosophical judgment contributed to the conclusion of ontological, epistemological, axiological and praxeological perspectives of further analysis. Based on the principle of unity of theory and practice, we managed to develop a system of practice-philosophical analysis in the application of semistructured interviews experts, who are followers, successors, critics and independent researchers, i.e., the "Carrier data" of the philosophical, anthropological, psychological and sociological memory legacy of Jean Baudrillard, the 'productive' figure in history, who for a reason is also the subject known as the "Europe's last prophet".

The memory studies about Jean Baudrillard in a semi-structured interview are based on the subsequent basic provisions: since in the philosophical study of methodology the key principle of analysis is the principle of efficiency, we decided to focus on our scientific intelligence including primary sources. By primary sources we determine not only works, books by J. Baudrillard, interview materials, recorded with him through life, those are documentaries about the object of research, but also the external circle of people, who knew Jean Baudrillard personally.

Traditionally, the study of memory human heritage is carried out on the examples of works and "traces of memory", which the man left behind. Such a "mine" of factual material is really a value for the study and understanding of heritage for future generations. (Kurdyumov \& Samarskiy, 1989). However, in our study we have researched the questions of a complex order: how memory about a person (who has 
6 Édition Printemps - Été 2019

left its mark on history by his results, relevant concepts, innovative ideas, application tools and technologies) allows future generations to learn from living "history lessons"? Is it appropriate to limit the understanding of the phenomenon of memory, for example, about the philosopher and thinker, within an approach stuck exclusively to his works and written sources studies?

According to the principle of unity of historical and logical, we chose a qualitative method of semi-structured interview, following the arguments: first, it is a philosophical reflection, therefore, we are interested in the meanings and interpretations of experts, scientists, deeply acquainted with the legacy of J. Baudrillard, that's why we don't choose mass, quantitative research; on-the second, heritage of Baudrillard has to be presented at a high professional level, since we are interested in multiple mechanisms of representation of memory; the third aspect is, we chose a semi-structured interview approach, that allowed, on the one hand, to ask the most common questions about memory and heritage of J. Baudrillard, and on the other hand, semi-structured interview afforded an opportunity to listen to the expert without being accused of prejudice, at the same time keeping the logic and course of our interview.

\section{Results and Discussions}

In 1949, Academician Grigory Popov formulated: "Everything that exists in the memory of a man, exists externally" (Popov, 1949). The academician reasoned as follows: "Let's consider what we have outside. What institutions, objects, we could attribute to memory"? (Popov, 1949: 45). Thus, G. Popov first proposed to study the existing institutions of memory as the results of successful activities, objectified, society, as fixed social relations of memory.

In the memory phenomenology, which for G. Popov is arranged on the following principle: 'the outer world is a mirror of human memory', therefore, the man does not invent anything, as he retrieves data from memory (Popov, 1949: 44). Regarding this principle, one of the key approaches to the study of memory is the so-called method of external research. For instance, if a person writes something down, photographs or depicts anything, thus he produces a separate block of memory, that is like 'taken away' from him (external memory data block).

Considering the memory research and its projections on the external level G. Popov concluded the hypothesis, that everything a person views around him are the results, "pulled out", taken away from human memory. "Outer world, or an external memory - this is the mirror of our human memory. And as each of us perceives the 
7 Édition Printemps - Été 2019

world differently, therefore, we share various memory issues, carrying a different set of data" (Popov, 1949: 46). G. Popov defined, as well: "... everything, that exists externally, is a display of human memory" (Popov, 1949).

The logical model of philosophical judgment of the memory phenomenology in 1949 by G. Popov is represented in the following pattern. To begin with, the outer world is a mirror of human memory, in accordance with this, a man does not invent anything, he receives data from memory. Secondly, this logical approach may also be recognized and used in the study of human mechanisms studying. According to the philosophical understanding of the author, the child also learns to interact with the external environment (Kurdyumov \& Samarskiy, 1989). Moreover, any person requires demonstrations and examples, i.e., some figures, that will become potential authorities in the process of learning and professional skills acquiring.

Moreover, Gregory Popov (Popov, 1949), by describing the theoretical model of human memory, mentioned and applied concepts "dynamic" and "static" memory blocks. The scientist straight explained the interaction of the data mechanisms of the two blocks of memory, as a result, we can trace on a logical figurative model in unity of two aspects: dynamics, future-oriented (dynamic memory block) and one, directed to the past (static memory unit). Since one of the objects of human skills is to accomplish the future (that is, an adult experiences the desired representational future must be achieved somehow, and this requires practical skills and actions) (Kagan, 1974); the author of the study pays particular attention to dynamic memory blocks. Next, we view the central attributive characteristics of the four dynamic blocks of human memory (Popov, 1949).

Dynamic memory block "circus": the key attribute characteristic of this block is skill (Popov, 1949: 47). It is in the "circus live skills": the most unusual, the most agile, the strongest people demonstrate their skills to the public: trainer skills, balancing skills, weightlifter skills, trickster, etc.

The key attributive characteristic of "theatre" block is the "role" (manifested in the activity as the ability to choose roles, embody them ,"play" in life "and thus achieve results and success in business) (Popov, 1949: 47).

Hence, in terms of understanding the processes of this block of memory by "university" we mean a certain institution, in which there is order, there are consultants, educational literature, and most importantly the methodology. There are people, coming, receiving this knowledge, there are seminars, offsets, etc. All this data simultaneously fits the block "university". Key attribute characteristic is methods and 
8 Édition Printemps - Été 2019

training program (that allows one to produce an answer to the question "how to do something")

The next block G. Popov defined as "religious institutions": "We will not appoint it a temple, church or any-what other institution. By this block models we mean the institutions of a religious nature". G. Popov did not insist on a specific name; he used the collective metaphor of "religious institutions". So, following logical reasoning on this topic, we should assume, each person has his own special religious knowledge, data, reviewers, mechanisms and the order of their use in cognition of the external world, its essence, pictures of the world as a system. The key attribute characteristic of this block is the mechanism (Popov, 1949: 48).

These four blocks of memory: "circus", "theater", "university" and "religious institution" are a dynamic memory blocks. Overall, these blocks reflect changes in the system of human worldview, in its activities and actions. In the implementation of these memory blocks events take place, the state of affairs changing. And each person possesses a configuration of these 4 (four) memory blocks.

Considering the philosophical views of Academician G. Popov, which are the result of epistemological and praxeological understanding of the environment and structure of memory, as well as the principles and criteria for the operation of the mechanisms of memory, based on the heuristic memory model, we shall comprehend the logic of controlled acquisition of professional skills. Heuristic model of dynamic memory blocks and the concept of activity approach directly ascertain the value and methodological practical significance of this philosophical judgment, since four key categories "skill-environment-training program-authority "form a system of education and self-education of a person on the way to his professional development" (Popov, 1949: 50).

Thus, in the process of life and activity, i.e., in the process of self-training and selfeducation there is a "skill", i.e., the category 'constructed' as a result of the interaction of four dynamic blocks of memory, i.e., the "theatre" - "circus" - "Religious building" - "Educational institution" through the use of education / self-education of the managed model "authority - environment - training program - habit". So, as a step of our scientific research, we represent the results of the study of the memorial figure - the world-famous thinker and philosopher Jean Baudrillard within the logic of the heuristic model of the structure of dynamic memory blocks and those constructs and components, which allow one to control the mechanisms of these memory blocks consciously, thereby enriching the personal set of skills and abilities (Popov, 1949). 
9 Édition Printemps - Été 2019

On the example of understanding the memory about Jean Baudrillard through the application of the epistemological concept of "authority - environment - training program - habit", we may consider practical examples which enrich the modern understanding of it, how to learn "history lessons" and learn from professionals (even if they are no longer physically present in our lives, still the distinctive memory of them is preserved).

Overall, five interviews are analysed in detail in our scientific investigation. Experts interviewed were invited to speak, were chosen according to the following criteria: level of intellectual training, the presence of deep works on the theoretical heritage of J. Baudrillard and (or) personal communication with J. Baudrillard, experience in philosophy, methodological and theoretical understanding of scientific works. Here-within we remark the experts were interviewed with the assistance of an employee of the Memory Institute, who has professional vocabulary and language of communication to convey an interview. As a result, three groups of experts were identified:

1. Followers and adherents, who personally knew J. Baudrillard and gained knowledge both directly and indirectly through co-working, interviewing and so on; who knew his surroundings and, accordingly, might provide personal data on the person and the scientist, as a figure of memory, i.e., the source of knowledge and skills.

2. Followers of J. Baudrillard, who did not know him personally, however studied and researched his works, concept and developed his experience. The study of such material allows us to understand the category of "environment" - that is, contribution of Jean Baudrillard as a philosopher and thinker.

3. Critics of the works and views of J. Baudrillard - opposing side, which also acts as a 'force' that comprehends and rethinks the role and significance of the results of individual activity in world history.

4. Researchers of J. Baudrillard, i.e. the independent experts, so-called "third parties", who did not know J. Baudrillard personally, do not recognize themselves his supporters and followers, but can present the results of their own perception of ideas, concepts and innovative advancements J. Baudrillard and express their potential significance in terms of application in resolving life problems in a dynamic context of the XXI century.

As such interviewers the following experts spoke: 
10 Édition Printemps - Été 2019

1. Dr. Arthur Kroker. Canadian author, editor, educator and researcher of political science, technology and culture. In addition to being a Professor of Political Science at the University of Victoria, Kroker serves as director of the Pacific Centre for Technology and Culture (PACTAC), located at the university. He is an editor of academic journal Ctheory, an international journal of theory, technology and culture.

2. Dr. Athina Karatzogianni. Associate Professor in Media and Communication at the University of Leicester, UK. She has an extensive record of publications and citations in disciplinary, field-specific and cross-disciplinary research outlets, and has demonstrated sustained success in securing research income from Research Councils UK and the European Commission. Her most recent book is (2018) Platform Economics: Rhetoric and Reality the "Sharing Economy".

3. Dr. Bernardo Attias. Professor in the Department of Communication Studies at CSUN. His research focus emphasizes cultural approaches to communication studies as well as communication-centered approaches to cultural studies. The emphasis of much of his work is on the political economy of mass-mediated events through the teachings of Michel Foucault and Jean Baudrillard.

4. Dr. Tim Otto Roth. German conceptual artist, composer and scholar. He develops a physical approach focusing on light phenomena in nature. In 2015 he published the "Cultural History of Shadow Pictures". He interviewed Jean Baudrillard about photography ("The Art of Disappearance")

5. Philip Beitchman. Professor Philip Beitchman teaches at Medgar Evers College (CUNY), translator of Baudrillard's books such as "Simulations" and "Fatal Strategies". He is the poet, researcher, translator, writer. Author of books: Alchemy of the Word: Cabala of the Renaissance; The View from Nowhere: Essays in Literature, Mysticism and Philosophy; The Theatre of Naturalism: Disappearing Act.

As a result of our scientific research, we shall observe the role and impact of the environment and "constructs" of world memory and history on the formation of memory about an authoritative personality, his works, achievements and creativity results, to determine the content of the memory of personality, as well as the ways these data can be used in modern conditions in terms of activity approach (Kagan, 1974). 'Environment' issue is the first one to be analysed within our research.

For the epistemological section, describing the influence of Jean Baudrillard's philosophical ideas on understanding the future and predicting future trends (dynamics of the "future in the present") Arthur Kroker, explains in general, at the moment 
11 Édition Printemps - Été 2019

the modern world has been completely described by Jean Baudrillard. And he prophetically identified two main movements, what the postmodern society of the future will look like. Firstly, it is a political economy. Jean Baudrillard best described in full in his book regarding the Political Economy of the Symbol how will "digitalization" take its place, changing the use of values, how it will get a symbolic value. The second direction of a philosophical ontological and epistemological understanding of the future, according to the reflections of A. Kroker, Jean Baudrillard has claimed, the social masses are always driven by a fatal death. This is their main engine, about which Nietzsche spoke, once again demonstrates us, how rapidly technology is gaining its scale and how this world is fully technologized, in the end finally coming to collapse.

Subsequently, in addition to the description of the two ontological principles of determining the system of formation of the environment of the future, A. Kroker adds that the third principle represents the theory of simulation, and the fourth outlines the principle of temptation, cultural temptation. Seduction is very important, from the viewpoint of Baudrillard, since he meant all things that within a specific time may simultaneously turn the other way.

The environment of the formation of actual experience can also be the works of an authoritative figure: books, articles, notes and other documented data. In particular, independent researcher Athina Karatzogianni was able to create her own concept of cyberconflicts, by studying the books of Jean Baudrillard and axiologically analyzing the concepts, proposed by him. So, answering questions about the reason she chose the works of Baudrillard, but not some other sociologists, philosophers; i.e. "why taking Baudrillard's approach?" Athina Karatzogianni, researcher, author, lecturer at the University of Leicester (United Kingdom) explained: "Firstly, when I was writing my doctoral dissertation, I researched Baudrillard a lot, since 2002 till 2004. I was just curious about what he writes about violence, since I studied cyberwar politics; then I was interested in his work. Well, through his work, I studied globalization and ethnic internet conflicts, hackers' issues, etc.".

The next question regarding cyberwar, clarifying the list of works by Baudrillard Athina Karatzogianni learned and applied and among the most informative and meaningful she outlined she created her own theory about cyber conflicts using three things. First - a new approach to the media, second - social movements, third - international conflicts. It was here Baudrillard helped her, since we analyse the media, digitalization impact, i.e. in these spheres Baudrillard is very useful, especially his 
12 Édition Printemps - Été 2019

books "Simulation and simulacra", "There was no war in the Gulf", "Spirit of Terrorism" and "Symbolic Exchange and Death".

The heritage of the French philosopher, according to the philosophical principle of the unity of historical and logical) could be viewed as a specific data environment, that acts as a catalyst and source in the praxiology of ideas, concepts and answers to new crushing questions in the context of the dynamic XXI century (Kurdyumov \& Samarskiy, 1989).

Considering Baudrillard's legacy as an environment of knowledge and analytical research, Bernardo Attias explains he did not study all the works of Baudrillard, but most of them. Recent books, after 2000 - 2002 he did not study, however, in general, he tried to look at Baudrillard with 'a wide eye', since he wanted to research the entire history of J. Baudrillard, starting with 1960-s, i.e. research his philosophical path, how his approach has changed in 70-s, his approach, when his book "Simulacrum and Simulation" was published in 80-s, as well as his final works, i.e., what is his approach defined in it.

Moreover, Bernardo Attias conducts a historical classification of the formation of scientific concepts and works of Baudrillard. That is no longer a direct sub-active characterization of Baudrillard as a figure, but his legacy is considered. We would like to demonstrate this issue within the interview analysis fragment:

Question: "Could Baudrillard's legacy be historically divided into 4 intervals, on 4 event groups, 4 group of philosophical analysis? If you do not mind, let's walk through each stage". Bernardo Attias replied that the first stage, Baudrillard was very close to Marxism, to semiotics, as at the first stage that he pays great attention to advertising, explains the society creates a need and when we buy an item, at the time of purchase we consume all the code. In the second stage, he and some other scientists would dwell on Baudrillard's work "Symbolic exchange and death", since within this period he begins to talk more about hyperreality, about endless semiosis and psychoanalysis. Bernardo Attias assumes, Baudrillard was extremely interested in psychoanalysis, he was interested in this even in 60-x years. and psychoanalysis greatly influenced him. In the second period there is a lot of talk about death and how death is a kind of motivator for something-either. I would divide the third period at the beginning 1980 year to the middle 80-x. It all starts with a simulation, including the book "Simulacrum and Simulation" and "Fatal Strategies", it is at this point that some scientists concluded certain unfair issues, starting to perceive and consider Baudrillard as a kind of elite anti-intellectual. 
13 Édition Printemps - Été 2019

From the standpoint of ontological and epistemological aspects of the analysis of 'the-future', scientist, representing the essence of the fourth stage, explains, that in this sense he does not have much knowledge here, however, he believes, that this is a certain period of philosophical understanding and creativity of J. Baudrillard, which floor associated with his book "America" and "Cold Memories". Basically B. Attias would highlight in the fourth period the essay "Spirit of Terrorism", which Baudrillard wrote in 2001. There was such a paragraph in the "Symbolic Exchange of Death", in which he expressed that actually the key thing marks our new era, our new era, i.e. 'a center of trade' - The Towers-twins. This displays, there are two identical buildings, they are a symbol, mirror simulation of the fact that everything else doesn't seem to matter".

According to Bernardo Attias, since Jean Baudrillard wrote about America, the French thinker even wrote about utopias and a certain 'telemorphosis'. Based on this epistemological and ontological classification of perception and understanding of the concepts of J. Baudrillard by his follower B. Attias, Jean Baudrillard was especially accurate in representing the vector of degradation of human cognition in the XXI century, indicating the most significant concepts of obstacles and dependencies, as well as tools, applying which a person is interested in effective self-realization, as the instrument is the key to achieving results. Moreover, the instrumental set allows one no longer depend on the trends of unpredictable simulation environment, as well as to become an independent object of his life, but not a "product or consequence of hyperreality".

Analyzing key ideas and concepts, i.e., a subject of philosophical reflection in the ontology and epistemology of the masses, to the question "If we count the most crucial Baudrillard's ideas, what would they look like?" B. Attias represents the following: the first idea is the "silent majority", as Richard Nixon wrote about it. Scholar believes it is a really significant fact, that the masses actually accept a simulated society; since the decision is produced by a silent majority, about which we know nothing. The second idea - simulation, hyperreality and how Baudrillard was influenced by Georges Bataille. Third is not quite an idea, but system of things and critique of political economy. The fourth idea is the fatality of strategy and terrorism, and then, whatever a revolution is forcing the system to move faster and show its true face.

Regarding the two ideas, that are the most complicated in understanding Baudrillard's philosophy Bernardo Attias believes there is such a thing as "reversibility": when Baudrillard explains something, he constantly uses a certain cyclicity 
14 Édition Printemps - Été 2019

or reversibility. Bernardo Attias thinks this is the hardest to understand, since even his students think at first, that everything is clear. However, there are always issues to clarify as one needs to analyse the early works of Baudrillard. Examples are the following aspects: from passion to ecstasy, from sexuality to pornography - everything is cyclical. The second idea is as follows: if Baudrillard explains 'hyperreality is more real than reality or disaster', this is an event, but even more than an event; or pornography - it's sex, but more than just sex. People misunderstand this and start blaming Baudrillard, B. Attias emphasises.

The fragments represent examples and evidence of the fact, the memory, created by man in history, is transformed for future generations into a data environment, analyzing and critically comprehending which is impossible not only to understand the preconditions and reasons for the past, but also the present, its 'total picture' as well as a potential picture of the future today. This example also updates the fact, the figure of Baudrillard in the science of memory clarifies questions of critical thinking about the picture of the future, awaiting humanity. Moreover, we consider it relevant to mention, Baudrillard was given a "second name" of "European last prophet". The study of ideas and concepts, described in his works is one of the most crucial fields and promising data environments for further research in social philosophy, anthropology, forecasting, and modeling of the future, as well as in others scientificallyapplied fields.

The next structural part of our study was the problem of authority (Popov, 1949).

Analyzing the philosophical influence of Baudrillard's works on the mass and collective consciousness, in terms of epistemological and axiological understanding, follower Philip Beitchman claims: "I feel, when it comes to a writer like Baudrillard, his goal was to make readers think, create, question some things. I believe Baudrillard is a 'continuation' of such people like Spinoza, Socrates, Kierkegaard. For me, Baudrillard is one of them".

This statement of F. Beitchman straight guides to the role of Jean Baudrillard in his memoirs to 1 . a potential authoritative figure (in terms of the structure of the generic concept memory unit according to G. Popov), 2. to a driving figure of the hero, catalyst who encourages critical and analytical thinking about their future and destiny (the context of the archetypological block of memory; Szondi, 1956) to a potential configuration of the prototype block of memory, i.e. figure responsible for the construction and formation of a philosophical worldview in space-temporal dynamics of 
15 Édition Printemps - Été 2019

self-realization of future generations (Popov, 1949). Furthermore, following the philosophical principle of effectiveness, F. Beitchman also continues that Baudrillard can be defined differently. For instance, there are two books, which interpret Baudrillard differently. In the first book, he is seen as a left-wing revolutionary, and in another book, he is not considered like this.

In terms of consideration and analysis of trends, determining the formation of an authoritative figure as an element of the prototypical environment of memory, we would love to mention the peculiar position of Arthur Kroker who stated Jean Baudrillard believed, today we face the world of the absurd as it is present everywhere: in modern politics, in the modern economy. Baudrillard, if one can say so, was an "artist" of pataphysics, and believed, that power as such has ceased to exist. In a fact, there is this constant absurdity, one witness with his eyes. "How much hyperreality can make you alive!".

Regarding the preceding fragment of the interview, it is considered logical to conclude, in terms of research on the activities and contributions of Jean Baudrillard, this figure is not only prototypical (a kind of "prophet", interpreter, capable to pay attention to current trends to follow the future), but also authoritative figure skilled to operate with complex philosophical categories (including an interdisciplinary approach).

Not just Philip Beitchman (being a follower) indicates the influence of Baudrillard's personality in the philosophical understanding of the problems of the future. Bernardo Attias, Professor, who teaches the teachings of Michel Foucault and Jean Baudrillard, to the question: "From your viewpoint, what is most interesting about Baudrillard?" in his reply explains, Baudrillard's interest is in that there is something prophetic in it, since he wrote in 1960-s about advertising, about popular culture, about the media - everything he predicted next happened and occurred, including what Baudrillard claimed in 70 - 80-s for politic and the crisis in the media (which is now taking its place), yet everything came true.

To the next question: "Can we say then Jean Baudrillard was primarily a sociologist?" Bernardo Attias explained one can call him a sociologist and it that will be attributed to him by right, still this is the question of semantics. Personally for B. Attias, Jean Baudrillard is a sociologist, researcher and a man, who was engaged in multiple scientific researches. 
16 Édition Printemps - Été 2019

Moreover, Jean Baudrillard was described as very specific. The point is, unlike Foucault, Deleuze, Bourdieu, Jean Baudrillard tried to analyze the complexity of systems. He realised that people are not neutral. It's not just the Earth and as there is something else, many 'other things'. Baudrillard was a professional anthropologist and even analyzed primitive societies. Thus, in the book "America" he mentioned such an interesting fact, that "the first primitive society in the modern arena - this is America". J. Baudrillard does not simply analyze different cultures, and does so with the help of some images, he concluded our civilization had not yet been described, as it is a new one. He studied different societies, compared and contrasted them, even studied the dreams of Africans. Baudrillard used parabols and metafors.

Overall, analysing these fragments, we could represent a following conclusion: on the one hand, with a sample of subjective perception of the figure of J. Baudrillard, and on the other, we observe this figure is remembered and characterized by B. Attias as a specific professional role (which corresponds to the attributive characteristic of the dynamic block of memory "theater" characterized by outstanding skills (for example, prognostication, which leads us to the skill issue, i.e., the key attribute characteristics of the memory unit "circus").

Research of tactics confirmed by Jean Baudrillard's as well as his research activities in the field of forecasting, description of current skills, his ability to extract conclusions and make unmistakable decisions, including the absence of reliable data terms, overall, it is significantly crucial and relevant within the circle of philosophically-practical tasks. The figure of J. Baudrillard, in our opinion, is rightfully a figure of authority, due to the availability of forecasting skills and knowledge of future trends. Hence, improvement and implementation of quality methodological programs, that take into account the practice of practical philosophical research today, in terms of post-pandemic, gets more relevant than ever.

A significant part of the study in a semi-structured interview was an optional step in the study of the characteristics of works and personality J. Baudrillard, i.e., is the issue of training program.

Baudrillard's works and his philosophical legacy stimulate not only a rethinking of concepts, but also to independent rethinking and self-learning in terms of forming their own "set of tools", about which we will speak in more detail later. Furthermore, we consider it necessary in the context of conceding the prognostic paradigms of considering the dynamics of the "past-the present-future" to analyze a fragment of the interview with Arthur Kroker. Interview with this follower of the school of 
17 Édition Printemps - Été 2019

Baudrillard is extremely valuable material in terms of activity approach to understanding the importance of the instrumental approach.

Baudrillard's tools stand as if around the project he analyzes, it looks like a clock, where an object is in the middle; and he applies all the tools to the object of study at the same time. In this case, some data is verified by other issues, that is the reason there are so few errors in Baudrillard's conclusions, allowing him to deliver an accurate forecast.

At this stage, we also point to the practical effect of Baudrillard's regulatory concept, who developed and applied heuristic models and epistemological tools, which also serve as a prerequisite for the formation of a review series in memory, functioning with the heritage of the Baudrillard school (that is, they determine the formation of the instrumental basis and understanding of mechanisms for solving problems in the process of life and activity).

To the question: "What do you think if a person studies the works of Baudrillard, what will one be able to learn, from your point of view?" Athina Karatzogianni assumes one can learn about symbolic violence, about the economy, which follows Marx, also one can realize the ways production and symbols relate to each other, the principles the signs relate to production. Analyzing the requirements of the environment and the 'rules of the game' in the geopolitical arena are changing, A. Karatzogianni continues, emphasizing Baudrillard wrote in his book, "only death can escape the code, so as not to be inside the code". At the moment, capitalism, if we take it as code, feels the problem, this huge number of deaths is a problem for him, they are trying to control somehow. The problem itself we are talking about is extremely significant.

As a relevant aspect for the study and field of philosophical understanding of Baudrillard's legacy, as well as a source of finding an effective training and self-study program, we pay attention to practical and at the same time philosophical application of the camera and the act of photography, introduced by Jean Baudrillard.

Jean Baudrillard himself (and this is confirmed by researchers) regularly carried a parallel between the books, which he wrote, and photos he made, arguing that principally it is the same action. Overall, an act of world cognition through the experience of meaningful photography by Baudrillard is one of the relevant skills for the contemporary the XXI century dynamics in terms of self-study, comprehension of modern trends, orientation in a changing environment and the development of the ability to see the "essence of content without a wrapper". 


\section{Édition Printemps - Été 2019}

For Jean Baudrillard photography is a "secret sacrament", since the philosopher explains: «...it sets me free". The act of liberation takes place according to Baudrillard in the following way: he has such a relationship with the camera, that "pushes" him to take the most high-grade pictures, on the one hand. On the other hand, pushes him to "Search for the moment" - and that pleases him.

As a result, we shall consider some causal symbiosis, that merges the figure of Jean Baudrillard into a "prophet", which allows people to see it, that they are unable to notice due to their dependence on hyperreality. That is, in one case, this symbiosis may be an identity, and otherwise, a philosophical act of emptiness, which forces a person to fill it with their own thoughts and ideas. Baudrillard in every act of photography intends to encourage people to think and act consciously. Thus, photography is an environment of scientific knowledge and the act of training with a camera (like make every picture as the best one since photo = result). A camera is a training tool; as an independent issue to practice it pretends to be an effective stimulator to achieve results (the latter is dedicated to the "skill" category).

The next dynamic part, which is the focus of our study is a skill.

In the practice-philosophical understanding of the legacy of Jean Baudrillard and an explanation of the differences between the tactics of action and the implementation of the skills of this authoritative figure from others, i.e., what exactly is the figure of Baudrillard in the structure of scientific activity differs from sociologists and other scientists of the time) Philip Beitchman remarked Baudrillard was distinctive from other sociologists at the time since Baudrillard not only analyzed or worked with numbers and statistics but also he had a completely different approach. He analyzed the world more widely, he considered trends, facts, as well as he had peculiar intuition. To give an example: now the coronavirus is everywhere, and all people are trying to mathematize and find some standard, simulate some rules, to which everything will be subordinated. All countries of the world act in the same way. But Jean Baudrillard did not practice his studies that way, since he understood every country and every nation is different and unique, for instance, regarding the mentality aspect.

Regarding the mentality component, the scholar identified the features of the current judgment of the effects of the environment on the dynamics of human activity, and also described philosophically-sociological diversity of individual scientific approach of J. Baudrillard in contrast to the mass mathematician-statistical approach to working with scientific data. Moreover, according to the logic of G. Popov and L. Szondi, such a scientific approach is not connected only with the controlled ability to 
19 Édition Printemps - Été 2019

work with the mechanisms of intuition, but also to describe the trends of the environment and the impact of environmental conditions on the mass and collective knowledge of processes, befalling today.

Contemporary conditions also update this approach and the need to forecast the conditions of 'the dynamic changing world'. Understanding these requirements and demand, they are urgent about efficiency, we can specify the works of Jean Baudrillard, who philosophically comprehended the world after global catastrophes (and simulated disasters), in the coming decades, interest in the practical direction will arise to memory scientifically-applied theories, which allow one to navigate in conditions of uncertainty while crediting daily results in the process of life and activity (Baudrillard, 2006).

Of particular interest is this aspect of the contribution to world memory, is the phenomenon of "Baudrillard's photography". Baudrillard considered the very skill of photography as something more 'vast' and functional than the act of engraving or the physical act of pressing a button. Further material is provided following the interview with researcher Tim Otto Roth who personally interviewed Jean Baudrillard.

Replying to the question: "Why did you talk about photos?" Tim Otto Roth has explained the point is, his main interest is not in photography, but in 'what is the nature of the image'. And that is the reason photography is one of the elements researched by him. 2000 - 2005 Tim Otto Roth took a significant number of interviews with many scientists of different disciplines; those who studied the humanities, the theorists, as well. The expert is curious 'what is an image'.

According to T. Otto Rott the act of photographing, in the first place, is a contemplative act rather than communicative. There is a moment of contemplation, the most intimate moment, a so-called secret game. Photography is a kind of disappearance creation, eliminating the value. And it comes from a very specific intention: since the present world (our current world) disappeared, one should play it to the very end. "This is the art of extinction" (Tim Otto Roth).

Baudrillard believed photographers are the "technology operators". As well as the camera can be a technology in the hands of the photographer and one is only the operator of this technology. However, Baudrillard himself never photographed like that. Even driving a car Baudrillard noted, he does not consider himself a 'technology operator'. A car for him was a certain instrument training him drive it perfectly. In fact, from the point of Baudrillard, the camera should make the person take great pictures. The camera should "force" one to become a great photographer. And this is 
20 Édition Printemps - Été 2019

one of Baudrillard's philosophical dogmas: relation to the camera, which will make you a great photographer; 'attitude' to the car, which will make one drive it flawlessly; choice of tactics, which will help a person win.

To the question: "I read your interview very carefully several times. From my point of view, you tried to "extract" a theory of photography from J. Baudrillard. Is that so?" Tim Otto Roth has replied that understanding Baudrillard's theory is similar to learning the way he takes pictures. Whereas so far it has not been written anywhere, why Baudrillard photographed, since he took so many pictures. T. Otto Rod was curious and eager to understand the reason the philosopher was acting like this. "Hence, Baudrillard's photos are not bad, however, they are not phenomenal. That is, these are good amateur photos". Still what's interesting: if it comes to photographs of Jean Baudrillard he studied media theory and what impact image possesses, and that is really interesting; moreover, everyone is trying to understand his theories, looking at his photos.

Overall, within the analysis of the interview with Tim Otto Roth, we have achieved the purpose of photography understanding according to the philosophy of Baudrillard is to make "the present world disappear", like to "play to the end". And this should be reflected in the photo. How is this achieved? Hence, according to the explanation of J. Baudrillard in an interview, the photography makes the world disappear, because a person sees only a fragment of it (its part) - i.e., the entire other world drops. The disappearance to the very end demonstrates the contrast of the existing "hyperreality, simulation and illusion crashed on this photo".

Regarding the results of our philosophical judgment of "living memory" about J. Baudrillard and his legacy, we shall outline the key points of philosophical reflection.

Considering the principle of theory and practice unity in terms of activity approach, we analyzed a model of attributive characteristics and dynamic components of memory reflected in the concepts of "skill", "role", "training methodology and program", as well as the "mechanism" issues. This task is aimed at ontological and epistemological understanding of the logic of dynamic memory blocks, i.e., human interaction with the external environment and its requirements, which contributed to the epistemological understanding of the logic of "environment-habit-training program-figure of authority". This praxeological concept is aimed at verifying the results of the philosophical understanding of theoretical models of the memory phenomenon in the practice of interpreting the philosophy of J. Baudrillard and his memory legacy. 
21 Édition Printemps - Été 2019

In the represented scientific exploration the ontological, epistemological, axiological, and praxiological aspects interpretation of the heuristic model of dynamic memory blocks introduced by G. Popov is defined. The results of philosophical and scientific activity of J. Baudrillard "living memory" through the prism of the heritage of the individual, his activities, contribution to the scientific advancement within the memory of experts represent methodological value in self-education and the practice of developing skills, relevant for future generations.

\section{Conclusions}

Summing up the key results of our study of the legacy of J. Baudrillard (moreover, these studies are ongoing), we would like to mention the following significant provisions.

Analysis of memory heritage J. Baudrillard based on the logical model "authorityenvironment-training program-skill" contributes to the conclusion of the philosophical concept of a prominent thinker, and directly determines the vector of efficient perception and data processing, exemplified by inheritance in the light of the tasks and requirements of the XXI century through the prism of activity and the need to prognosticate and acquire relevant skills.

The model of research of dynamic blocks of memory offered allows one to "unpack" the memorial processes about the individual and its significance for the sphere of activity (in our case - philosophical, theoretical activity J. Baudrillard), as well as for the activity approach in the key of understanding of prospects and rational approaches in methodology and aspects of self-learning in the XXI century.

Furthermore, following in our scientific exploration the data, represented by adherents and followers of the school of Baudrillard, in the context of memory, we should recognize the figure of Jean Baudrillard as a prototypical figure in the XXI century - including, based on the level of criticism of his opponents about the activity procedural significance of the inheritance of J. Baudrillard.

The arousing significant role of axiology and the reflection of the memory mechanisms in determining the value of J. Baudrillard. The next conclusion is, Jean Baudrillard in social memory becomes a prototype, an authoritative "timeless" figure, that provides the basic definitions of the spatially-time category "hyperreality". Moreover, it describes the logic and features, shows in his works how not to exist as a result of simulations and hyperreality - all this indicates relevance, specificity, and integrity of memory about the legacy of J. Baudrillard. Contrasting issue is, in this 
22 Édition Printemps - Été 2019

case (according to Popov's categorization), that is also an inherent figure of the authority configuration model, philosophy of which effectively allows a person to produce results and achieve goals in his life.

The key in the praxeological and axiological section of our scientific analysis has been the activity approach; epistemological and axiological aspects of the analysis of the philosophical heritage of the school J. Baudrillard also actualizes current philosophically-methodological researches and perspective studies aiming at developing programs and systems for training experts and professionals, skills and abilities which meet the requirements of the environment and the XXI century, which is dynamically changing been thus characterized with continuous processes of digitalization, "loss" of activity attributions merging into "virtual space", replacement of physical socially-communication space internet-resources and social networks, as well as "extending hyperreality", i.e., the concept introduced directly by the prominent French philosopher and sociologist Jean Baudrillard.

The concept of "hyperreality" and its expansion, followed by the replacement of values, priorities, about the efficiency of logic - this is one of the basic spatial-time characteristics, which dictate a systemic change in the environment of the XXI century. In the philosophical heritage of Jean Baudrillard, this block of memory not only describes the arrow trends of time "past-the present-future", but also allows one to comprehend spatially-time characteristics, which in the epistemological and praxeological understanding of the methodology of education of the XXI century also determines the vector of further relevant research.

\section{References}

Baudrillard, J. (2006). Passwords. From fragment to fragment. Ekaterinburg: U-Faktoria, $240 \mathrm{p}$.

Baudrillard, J. (2017). Fatal Strategies / J. Baudrillard; J. Baudrillard; transl. by A. Kachalova. Moscow: RIPOL-klasik.

Kagan, M.S. (1974). Human Activity (Experience of System Analysis). Moscow: Politizdat.

Kurdyumov, S.P., Samarskiy, A.A. (1989). Paradoxes of the multivariate world - the world around us. Hypotheses. Forecasts. Future of science. Intern. Yearbook. Moscow: Knowledge, 22. 13-22. 
23 Édition Printemps - Été 2019

Popov, G.S. (1949). SRIM Archive (Memory SRI, by G. Popov) F. 3 ("Heritage of G. Popov" fund, Vienna 1940). Inv. 3, 1949 1. FC.1-7. 24 - 58. [Memory phenomenology: three Approaches to Study Memory. Manuscript]

Szondi, L. (1956). Ich-Analyze. The foundation for the development of deep psychology. Part 1. - Bern: Hans Huber. 